See discussions, stats, and author profiles for this publication at: https://www.researchgate.net/publication/331760061

\title{
Translating Marine Animal Tracking Data into Conservation Policy and Management
}

Article in Trends in Ecology \& Evolution · March 2019

Dol: 10.1016/j.tree.2019.01.009

CITATIONS

114

50 authors, including:

Graeme C Hays

Deakin University

353 PUBLICATIONS 25,205 CITATIONS

SEE PROFILE

Steven Bograd

University of California, Santa Cruz

282 PUBLICATIONS 13,637 CITATIONS

SEE PROFILE
2,313

Helen Bailey

University of Maryland Center for Environmental Science

78 PUBLICATIONS 4,623 CITATIONS

SEE PROFILE

B. William Don Bowen

Bedford Institute of Oceanography

211 PUBLICATIONS 11,053 CITATIONS

SEE PROFILE

Some of the authors of this publication are also working on these related projects:

Long-term distributional and behavioural studies of coastally-occurring cetacean species in northeast Scottish waters View project

Predator-Prey Interactions View project 


\section{Translating Marine Animal Tracking Data into Conservation Policy and Management}

Graeme C. Hays,,$^{1, \star}$ Helen Bailey, ${ }^{2}$ Steven J. Bograd, ${ }^{3}$ W. Don Bowen, ${ }^{4}$ Claudio Campagna, ${ }^{5}$ Ruth H. Carmichael, ${ }^{6,7}$ Paolo Casale, ${ }^{8}$ Andre Chiaradia, ${ }^{9}$ Daniel P. Costa, ${ }^{10}$ Eduardo Cuevas, ${ }^{11,12}$ P.J. Nico de Bruyn, ${ }^{13}$ Maria P. Dias, ${ }^{14,15}$ Carlos M. Duarte, ${ }^{16}$ Daniel C. Dunn, ${ }^{17}$ Peter H. Dutton, ${ }^{18}$ Nicole Esteban, ${ }^{19}$ Ari Friedlaender, ${ }^{10,20}$ Kimberly T. Goetz, ${ }^{21}$ Brendan J. Godley, ${ }^{22}$ Patrick N. Halpin, ${ }^{17}$ Mark Hamann, ${ }^{23}$ Neil Hammerschlag, ${ }^{24}$ Robert Harcourt, ${ }^{25}$ Autumn-Lynn Harrison, ${ }^{26}$ Elliott L. Hazen, ${ }^{3}$ Michelle R. Heupel, ${ }^{27}$ Erich Hoyt, ${ }^{28,35}$ Nicolas E. Humphries, ${ }^{29}$ Connie Y. Kot, ${ }^{17}$ James S.E. Lea, ${ }^{30}$ Helene Marsh, ${ }^{23}$ Sara M. Maxwell, ${ }^{31}$ Clive R. McMahon, ${ }^{25,32,33}$ Giuseppe Notarbartolo di Sciara, ${ }^{34,35}$ Daniel M. Palacios, ${ }^{36}$ Richard A. Phillips, ${ }^{37}$ David Righton, ${ }^{38,39}$ Gail Schofield, ${ }^{40}$ Jeffrey A. Seminoff, ${ }^{41}$ Colin A. Simpfendorfer, ${ }^{23}$ David W. Sims, ${ }^{29,42,43}$ Akinori Takahashi, ${ }^{44}$ Michael J. Tetley, ${ }^{35}$ Michele Thums, ${ }^{45}$ Philip N. Trathan, ${ }^{35}$ Stella Villegas-Amtmann, ${ }^{10}$ Randall S. Wells, ${ }^{46}$ Scott D. Whiting, ${ }^{47}$ Natalie E. Wildermann, ${ }^{48}$ and Ana M.M. Sequeira ${ }^{49}$

There have been efforts around the globe to track individuals of many marine species and assess their movements and distribution, with the putative goal of supporting their conservation and management. Determining whether, and how, tracking data have been successfully applied to address real-world conservation issues is, however, difficult. Here, we compile a broad range of case studies from diverse marine taxa to show how tracking data have helped inform conservation policy and management, including reductions in fisheries bycatch and vessel strikes, and the design and administration of marine protected areas and important habitats. Using these examples, we highlight pathways through which the past and future investment in collecting animal tracking data might be better used to achieve tangible conservation benefits.

\section{Tracking Data and Conservation Policy}

The advent of reliable technology to track individual animals long-term (often $>1$ year), throughout marine and terrestrial environments, has produced a golden era for animal tracking studies [1,2]. In marine systems, long-term tracking is now routine for fish (e.g., bony fish, sharks, rays), birds (e.g., penguins, albatrosses, and shearwaters), mammals (e.g., seals, sirenians, dolphins, and whales), and reptiles (e.g., sea turtles). One driver behind growth in marine animal tracking studies is the need for distribution and movement data to inform conservation policy and management. In a recent literature review of 13349 'movement ecology' papers published between 1990 and 2014, 35\% ( $n=4672$ papers) mentioned 'conservation' [3]. However, the value of tracking data to inform policy is often presented as a 'given', yet not explicitly demonstrated [4]. For example, a review of the conservation impact of sea turtle tracking studies highlighted that of 369 papers published between 1982 and 2014 (supported by a questionnaire-based survey of 171 sea turtle researchers), there were only 12 instances where tracking findings led to clearly identifiable real-world changes in conservation practice, even though $>120$ papers identified conservation as a rationale for the work [5]. This suggests that either tracking and distribution data are not considered to be relevant or barriers exist which prevent their uptake by policy makers and managers, to the

\section{Highlights}

The value of animal tracking data to inform policy is illustrated by case studies from around the world and with a broad range of taxa.

Application of tracking data to policy and management can take various pathways, and engagement with stakeholders might often not be made by the original data collectors.

The impact of tracking data on policy and management can be improved if data collection and analyses target specific needs for management outcomes.

Early engagement among the data collectors and the stakeholders involved in policy development and implementation is important to help translate tracking data into conservation outcomes.

${ }^{1}$ Deakin University, Geelong, Victoria, Australia

${ }^{2}$ Chesapeake Biological Laboratory, University of Maryland Center for Environmental Science, Solomons, MD 20688, USA

${ }^{3}$ NOAA Southwest Fisheries Science Center, Environmental Research Division, Monterey, CA 93940, USA ${ }^{4}$ Population Ecology Division, Bedford Institute of Oceanography, Dartmouth, 


\section{Trends in Ecology \& Evolution}

detriment of evidence-based conservation [4,6-8]. There can be many reasons for this apparent disjunct between tracking effort and implementation into conservation policy. It might be that policy outcomes arise only after a formal research paper has been published, and hence the direct connection between science and policy might not be clear; end-users might not be aware of or have access to data published in the scientific literature; results from tracking studies might not be delivered to management and policy arenas in a 'useable' format [9]; or policy makers or managers might not have been involved in the initial study design and so their needs were not addressed [4]. However, animal tracking is often the only way to determine species overlap with threats and thus to assess potential impacts of those threats for species that range widely in the oceans $[10,11]$. So there is great potential for animal tracking data to inform marine management.

Here we draw on the accumulated experiences of scientists in the diverse field of marine animal tracking $[6,12]$ to show how movement and distribution data have informed conservation actions. To illustrate the breadth of studies, we highlight examples from various taxa and regions, with movement data collected using a range of techniques. We present case studies that operate at different spatial scales, from local levels to entire ocean basins. We illuminate pathways and also identify obstacles for successful uptake of tracking data into policy and management, and our hope is that this review will provide direction to help researchers translate their animal tracking data into more effective conservation practice.

\section{Identifying Case Studies}

We identified leading experts in the field of marine animal tracking and asked them to identify case studies where information they had published on animal movements or distribution led to policy change or management action. Experts were selected from the list of previous coauthors on two recent papers that involved tracking data from across multiple taxa [6,12] or had contributed data to two ongoing international collaborative projects, the Marine Megafauna Movement Analytical Program (MMMAP; https://mmmap.wordpress.com) and Migratory Connectivity in the Oceans (MiCO; https://mico.eco), that are synthesizing tracking data across multiple taxa and developing tools to provide policy makers and managers with greater access to usable results from tracking studies. Additional experts were also solicited based on their publications and experience.

\section{Results}

We identified examples where marine animal tracking data have helped conservation outcomes to be achieved across the world's oceans (Figure 1).

\section{Seabirds}

An exemplar for the conservation value of tracking data is the development of bycatch mitigation measures for albatrosses in South Georgia waters (Figure 1, example 1; Figure 2). Additional tracking of multiple penguin species (macaroni: Eudyptes chrysolophus; king: Aptenodytes patagonicus; gentoo: Pygoscelis papua), other flying birds (northern and southern giant petrels: Macronectes halli and Macronectes giganteus; white-chinned petrels: Procellaria aequinoctialis; South Georgia shags: Leucocarbo [atriceps] georgianus), and also mammals (Antarctic fur seals: Arctocephalus gazella) [13] were key to the establishment in 2012 of the South Georgia and South Sandwich Islands marine protected area (MPA) (see Glossary) (Figure 1, example 2). This MPA is now completely closed to all fishing for Antarctic krill (Euphausia superba) during the summer breeding season of krill-dependent predators, and all fishing at South Georgia is restricted to areas $>30 \mathrm{~km}$ from shore in the winter, with a suite of similar protection measures at the South Sandwich Islands. Other provisions are also included
NS B2Y 4A2, Canada

${ }^{5}$ Wildlife Conservation Society, Marine Program, Buenos Aires, 1414 Argentina

${ }^{6}$ University Programs, Dauphin Island Sea Lab, Dauphin Island, AL 36528 , USA

${ }^{7}$ Department of Marine Sciences, University of South Alabama, Mobile, AL 36688, USA

${ }^{8}$ Department of Biology, University of Pisa, Pisa, Italy

${ }^{9}$ Conservation Department, Phillip Island, Nature Parks, Victoria, Australia ${ }^{10}$ Department of Ecology and Evolutionary Biology, University of California, Santa Cruz, CA 95060, USA

${ }^{11}$ CONACYT - Research Center of Environmental Sciences, Faculty of Natural Sciences, Universidad Autonoma del Carmen, Campeche 24180, Mexico

${ }^{12}$ Pronatura Peninsula de Yucatan, Yucatan 97205, Mexico

${ }^{13}$ Mammal Research Institute, Department of Zoology \& Entomology, University of Pretoria, Hatfield 0028 , South Africa

${ }^{14}$ BirdLife International, Cambridge CB2 3QZ, UK

${ }^{15}$ MARE - Marine and Environmental Sciences Center, ISPA - Instituto Universitário, 1149-041 Lisboa, Portugal ${ }^{16}$ King Abdullah University of Science and Technology (KAUST), Red Sea Research Center (RSRC), Thuwal, 23955-6900, Saudi Arabia

${ }^{17}$ Marine Geospatial Ecology Lab, Nicholas School of the Environment, Duke University, Durham, NC, USA ${ }^{18}$ Marine Mammal and Turtle Division, National Marine Fisheries Service, National Oceanic and Atmospheric Administration, La Jolla, CA 92037, USA ${ }^{19}$ Department of Biosciences, Swansea University, Swansea SA2 8PP, Wales, UK

${ }^{20}$ Institute for Marine Sciences, University of California Santa Cruz, Santa Cruz, CA 965060, USA

${ }^{21}$ National Institute of Water \& Atmospheric Research Ltd (NIWA), Greta Point, Wellington, New Zealand ${ }^{22}$ Marine Turtle Research Group, Centre for Ecology and Conservation, School of Biosciences, University of Exeter, Cornwall Campus, Penryn TR10 9EZ, UK ${ }^{23}$ College of Science and Engineering, James Cook University, Townsville, QLD 4811, Australia

${ }^{24}$ Rosenstiel School of Marine \& Atmospheric Science, Abess Center for Ecosystem Science \& Policy, University of Miami, Miami, FL 33149, USA ${ }^{25}$ Department of Biological Sciences, Macquarie University, Sydney, NSW 


\section{Trends in Ecology \& Evolution}

in the MPA that reduce bycatch, limit impacts on harvested stocks, and limit interactions with marine benthos [13]. Protection is provided by a fisheries patrol vessel, ensuring illegal, unregulated and unreported (IUU) fishing has been eliminated. The fisheries in South Georgia waters are certified by the Marine Stewardship Council (https://www.msc.org), providing evidence of the careful management.

Tracking data from Pygoscelis penguins have revealed predictable feeding areas and highlighted areas of potential competition with the regional fishery for Antarctic krill at the Antarctic Peninsula and at nearby archipelagoes [14,15]. The data from Adélie penguins (Pygoscelis adeliae) were used to help create the South Orkney Islands southern shelf MPA, the first MPA designated entirely within internationally managed waters (with approxi-

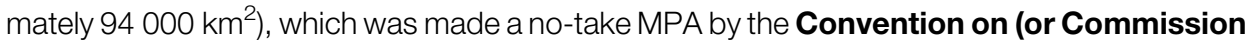
for) the Conservation of Antarctic Marine Living Resources (CCAMLR) in 2009 (Figure 1, example 3).

Tracking of seabirds (and seals) was used to identify the most important areas for these species in the waters around the Falkland Islands [16]. The analyses were conducted by BirdLife International in collaboration with the South Atlantic Environmental Research Institute (Falkland Islands Government). The results of this study informed both the establishment of a Marine Spatial Plan for the Falkland waters [16] and the Assessment of Fishing Closure Areas as sites for wider marine management in the Falkland Islands [17] (Figure 1, example 4). Information on at-sea distributions of albatrosses and large petrels, mainly from tracking studies, has also been used at a global scale by the multilateral Agreement on the Conservation of Albatrosses and Petrels (ACAP) in a framework for assessing and prioritizing the bycatch risk from different fisheries [18].

\section{Marine Mammals}

As with seabirds, tracking data have helped in the designation of protected zones for marine mammals. For example, insights from satellite tracking the movements of Galápagos sea lions (Zalophus wollebaeki) [19] encouraged the redesign of the Galápagos Marine Reserve zonation (Figure 1, example 5). New conservation zones took effect in 2017 and prohibited any type of fishing activity. In addition, tracking data were incorporated into new regulations to define 'sustainable use zones', where fisheries are managed to minimize impacts on sea lions.

Tracking data have been used to help define stocks of bottlenose dolphins (Tursiops truncatus) in south-eastern US waters (Figure 1, example 6), an important process for determining how the US Marine Mammal Protection Act (MMPA) should be applied. Historically, quotas for livecapture removals for public display, research, and the military, were established for large regions of coastal waters based on where commercial collectors operated, rather than on the ecology of the animals [20]. Repeated visual observations of tagged dolphins in and around Sarasota Bay, Florida, combined with radio-telemetry, allowed the home range of a resident community of bottlenose dolphins to be defined for the first time [21]. Consequently, the US National Marine Fisheries Service (NMFS) accepted that bottlenose dolphins inhabiting many of the bays, sounds, and other estuaries adjacent to the Gulf of Mexico form discrete communities that under the MMPA need to be maintained [22].

In northern Australia, tracking data have been used to improve management of dugongs (Dugong dugon) (Figure 1, example 7). Since the 1980s, aerial surveys over tens of thousands of square kilometers have identified the distribution and abundance of dugongs in the Great Barrier Reef World Heritage Area (GBRWHA) and Torres Strait. Major improvements in the
2109, Australia

${ }^{26}$ Migratory Bird Center, Smithsonian Conservation Biology Institute, Washington, DC 20008, USA

${ }^{27}$ Australian Institute of Marine Science, Townsville, QLD 4810, Australia ${ }^{28}$ Whale and Dolphin Conservation, Bridport, Dorset, UK

${ }^{29}$ Marine Biological Association of the United Kingdom, The Laboratory, Plymouth PL1 2PB, UK ${ }^{30}$ Department of Zoology, University of Cambridge, Cambridge, UK

${ }^{31}$ School of Interdisciplinary Arts and Sciences, University of Washington, Bothell Campus, Bothell, WA 98011, USA

${ }^{32}$ Ecology and Biodiversity Centre, Institute for Marine and Antarctic Studies, University of Tasmania, Hobart, TAS 7004, Australia

${ }^{33}$ Sydney Institute of Marine Science, Mosman, NSW 2088, Australia

${ }^{34}$ Tethys Research Institute, 20121 Milano, Italy

${ }^{35}$ IUCN Joint SSC/WCPA Marine Mammal Protected Areas Task Force, Gland, Switzerland

${ }^{36}$ Marine Mammal Institute and Department of Fisheries and Wildlife, Oregon State University, Newport, OR 97365, USA

${ }^{37}$ British Antarctic Survey, Natural Environment Research Council, Cambridge, CB3 OET, UK ${ }^{38}$ Cefas Laboratory, Suffolk, NR33 OHT, UK

${ }^{39}$ School of Environmental Sciences, University of East Anglia, Norwich, NR4 7TJ, UK

${ }^{40}$ School of Biological and Chemical Sciences, Queen Mary University of London, E14NS, London, UK

${ }^{41}$ Marine Turtle Ecology and Assessment Program, NOAA-Southwest Fisheries Science Center, La Jolla, CA 92037, USA ${ }^{42}$ Ocean and Earth Science, National Oceanography Centre Southampton, University of Southampton, Waterfront Campus, Southampton, SO14 3ZH, UK

${ }^{43}$ Centre for Biological Sciences, Building 85, University of Southampton, Highfield Campus, Southampton, SO17 1BJ, UK ${ }^{44}$ National Institute of Polar Research, Tachikawa, Tokyo 190-8518, Japan ${ }^{45}$ Australian Institute of Marine Science, Indian Ocean Marine Research Centre (M096), University of Western Australia, Crawley, WA 6009, Australia ${ }^{46}$ Chicago Zoological Society's Sarasota Dolphin Research Program, c/o Mote Marine Laboratory, Sarasota, FL 34236, USA

${ }^{47}$ Marine Science Program, Department of Biodiversity, Conservation, and Attractions, Kensington, WA 6151 , 


\section{Trends in Ecology \& Evolution}

method to correct for availability bias were based on data from satellite-tracked dugongs fitted with time-depth recorders, thus enabling estimation of the time a dugong spends in the experimentally determined detection zone for various survey conditions [23]. These corrections make a substantive difference to the dugong population estimate from Torres Strait, where most animals feed in deeper water, and have added to the evidence that the dugong harvest in Torres Strait is sustainable [23]. This information is being used to brief local communities in Torres Strait, the Regional Authority, Commonwealth and Queensland Ministers for the Environmental (Australia), and their advisors. Within the GBRWHA, data from the dugong aerial surveys and satellite tracking [24] have been used to: (i) design dugong protection areas in which commercial gill netting is managed [25], and (ii) inform the rezoning of the Great Barrier Reef Marine Park to protect dugongs [26].

In eastern Canadian waters, satellite tags fitted to beluga whales (Delphinapterus leucas) from the Eastern Hudson Bay stock filled gaps in traditional knowledge and helped to better define stocks (Figure 1, example 8). Data revealed that beluga whales seasonally migrate along the coasts of Hudson Bay and Hudson Strait, and that the distribution of stocks differed seasonally $[27,28]$. Such improved understanding of stock structure allowed allocation of subsistence harvests to the appropriate stock and allowed more robust estimation of population size and sustainable harvest levels [29].

With utility to a variety of end users, tracking data can provide a myriad of conservation benefits. For example, for the West Indian manatee (Trichechus manatus), previously considered an occasional visitor in areas west of Florida waters, satellite telemetry and opportunistic sighting data indicated extensive use of northern Gulf of Mexico habitats \{[30]; Carmichael, R.H. and Aven, A. (2017) GPS tracking of West Indian manatees (Trichechus manatus latirostris) tagged in Mobile Bay, Alabama (2009-2015). Dauphin Island Sea Lab: Data Management Center. (http://cf.disl.org/datamanagement/metadata_folder/ DISL-Carmichael-Aven-001-2017.xml)\} (Figure 1, example 9). This information on manatee distribution has been used by a range of end users to minimize impacts of waterway bridge building, as part of management planning for habitat protection, to determine endangered species classification, and to improve the design of boating corridors to minimize boat strikes on manatees. End users included the US Fish \& Wildlife Service, Alabama Division of Wildlife and Freshwater Fisheries, Alabama Department of Transportation, US Army Corps of Engineers, National Oceanic and Atmospheric Administration (NOAA) Marine Debris program, Weeks Bay National Estuarine Research Reserve, the US Coast Guard, and environmental consulting firms or non-governmental organizations. In Florida, tracking data have also been used to assess the effectiveness of recovery efforts for manatees and other species across decades following rehabilitation [31]. In some cases photographic identification (photo-ID), rather than transmitters, have provided information on marine mammal movements that has helped conservation (Box 1).

Fish

Fish tracking data have informed international conservation efforts (e.g., of basking sharks, Cetorhinus maximus; Figure 3), influenced MPA design at multiple spatial scales (Box 2), and contributed to stock management (e.g., Atlantic cod; Gadus morhua). In the North Sea and UK waters, Atlantic cod has been a popular target for the European fishing industry for over a century. Quota management for this species in EU waters is discussed each year within the EU Fisheries Council, informed by scientific advice given by the International Council for Exploration of the Sea (ICES). Cod tracking data (e.g., [32]) have been used to inform EU stock management policy since 2005 and were used in ICES triennial
Australia

${ }^{48}$ Marine Turtle Research, Ecology and Conservation Group, Department of Earth, Ocean and Atmospheric, Science, Florida State University, Tallahassee, FL 32306-4320, USA

${ }^{49}$ IOMRC and The University of Western Australia Oceans Institute, School of Biological Sciences, University of Western Australia, Crawley, WA 6009, Australia

*Correspondence:

g.hays@deakin.edu.au (G.C. Hays). 


\section{Trends in Ecology \& Evolution}

benchmarking reports in 2009, 2012, and 2015 (Figure 1, example 10). In general, evidence from tracking has been used to support existing stock definitions. For example, 'North Sea cod' is defined as the stocks within the eastern English Channel north to the Shetland Islands and the southern Norwegian coastline between $50^{\circ} \mathrm{N}$ and $62^{\circ} \mathrm{N}$. The tracking data provide confidence that this stock definition is appropriate. A more recent application of tracking tools is to assess post-release mortality rates of fish following interactions with fishing gear, with these data being directly integrated into fisheries stock assessments to estimate sustainable fishing levels [33,34].

Fish tracking data can also be used to identify essential fish habitat (EFH). NMFS is required to identify and describe $\mathrm{EFH}$, minimize to the extent practicable the adverse effects of fishing on $\mathrm{EFH}$, and identify other actions to encourage the conservation and enhancement of EFH [35]. In 2015, NMFS completed a 5-year EFH review of species, including billfish, tunas, and sharks (Figure 1, example 11). Using fish tracking data, NMFS established new EFH boundaries across the entire US Exclusive Economic Zone [35], including for bull (Carcharhinus leucas), tiger (Galeocerdo cuvier), and great hammerhead (Sphyrna mokarran) sharks.

Acoustic tracking of juvenile blacktip sharks (Carcharhinus limbatus) in a coastal nursery area in Florida over 4 years was used to estimate mortality rates (Figure 1, example 12). Sharks were tracked within a passive acoustic receiver array which ensured continuous detection of individuals throughout their residency within the bay. Based on the fate of tracked individuals (apparent mortality, removal by fishermen, survival, and exit from the study site) estimated mortality rates for neonate and juvenile sharks were 61\%-91\% [36]. At the time, the blacktip shark was the second most commonly caught species in commercial shark fisheries in the southeast USA but mortality rate was poorly defined. NMFS incorporated these new mortality values into stock assessments used to determine annual fishery quotas [37]. There is the potential for more widespread use of tracking data in stock assessment models.

In Australia, acoustic tagging of the blue groper (Achoerodus viridis) revealed an extremely high level of site fidelity and complete lack of dispersal of adult fish, leading to the suggestion that conservation networks of small MPAs might prove highly effective [38] (Figure 1, example 13). At the time there was considerable pressure from local recreational fishermen to remove the notake areas. The results of the tracking study were widely promulgated on television, in local media, and by the state government and were presented at stakeholder meetings over a period of 12 months. Based on the tracking results, a network of small reserves in the Sydney metropolitan area was reconfirmed.

\section{Sea Turtles}

In July and August 2012, a mass-stranding of 786 loggerhead sea turtles (Caretta caretta) along the Pacific coast of Baja California, Mexico, was coupled with a report of substantial sea turtle bycatch in the gillnet fishery of Baja California Sur. These events prompted NMFS to formally identify that Mexico lacked an effective regulatory program to end or reduce North Pacific loggerhead turtle bycatch in the gillnet fishery operating in the Gulf of Ulloa, an important loggerhead habitat in the coastal ocean [39], pursuant to the High Seas Driftnet Fishing Moratorium Protection Act. As indicated in this Act, Mexico had 2 years, beginning in January 2013, to develop a regulatory program to reduce or eliminate this bycatch, or risk losing access to US markets for fisheries exports [40]. In April 2015, Mexico provided the USA with its regulatory measures, which included the implementation of a mortality cap of 90 loggerhead turtles per season, establishment of an observer program (including vessel monitoring and video surveillance), and development of a spatially tiered reserve system in

\section{Glossary}

\section{Agreement on the Conservation} of Albatrosses and Petrels (ACAP): treaty (ratified in 2004) that seeks to conserve albatrosses and petrels by coordinating international activity to mitigate known terrestrial and marine threats to their populations.

Convention on Biological

Diversity (CBD): treaty (effective at the end of 1993) recognizing conservation of biodiversity (ecosystems, species, and genes) as 'a common concern of human kind' and aiming at developing strategies for its conservation and sustainable use. It advocates the use of the precautionary principle, whereby measures to minimize threats to biodiversity should take place despite lack of full scientific certainty.

Convention on (or Commission for) the Conservation of Antarctic Marine Living Resources (CCAMLR): part of the Antarctic Treaty System (established in 1982) aiming at preserving marine life and environment in, and around, Antarctica. Composed by 24 countries and the European Union as Members States, the Commission is based in Tasmania, Australia. CCAMLR recently declared the world's largest marine park in the Ross Sea.

Convention on International Trade in Endangered Species of Fauna and Flora (CITES): international agreement, adopted in 1963 and entering into force on 1 July 1975 , providing a framework for parties to protect endangered fauna and flora and ensure that international trade of specimens does not pose a threat to their survival.

Convention on Migratory Species of Wild Animals (CMS): treaty under the United Nations Environment Programme aiming at conserving migratory species, their habitats, and migratory paths. The Convention lays the legal foundation for coordinated conservation measures between parties through which migratory animals pass, using a range of accords between parties (from memoranda of understanding to legally binding agreements). Ecologically or Biologically Significant Areas (EBSAs): areas identified as important for the healthy 


\section{Trends in Ecology \& Evolution}

part of the area where loggerhead bycatch was known to occur (Figure 1, example 14). In the development of the reserve design, Mexico's Ministry of the Environment and Natural Resources [41] considered satellite telemetry data from 43 loggerhead turtles [42], as well as loggerhead aerial survey data [43]. The new loggerhead-focused Fishery Reserve encompassed $8848 \mathrm{~km}^{2}$, limiting fishing access to a highly productive area for commercially relevant finfish species, and fundamentally changing management in a region that had for generations operated with minimal bycatch reduction standards. The Fishery Reserve, initially set to last 2 years, was declared permanent in May 2018 and expanded to encompass the entire Gulf of Ulloa.

In Gabon, Central Africa, satellite tracking of sea turtles has been integral to the extension of an MPA network to encompass $27 \%$ of the nation's exclusive economic zone (EEZ) (Figure 1, example 15). Tracking data from leatherback (Dermochelys coriacea) and olive ridley turtles (Lepidochelys olivacea) were used to help determine critical habitats and overlap with human activities [44-47]. These data were key elements of the expansion of two MPAs: (i) Mayumba National Park, expanded to the limit of the EEZ encompassing the habitat of leatherback turtles at sea in Gabon, as well as the internesting habitat of olive ridley turtles in Gabonese waters; and (ii) Pongara National Park, expanded from a largely terrestrial protected area to incorporate a large portion of the marine and estuarine habitat offshore [46]. Similarly, in 2013, the Mexican federal government requested a technical evaluation of the relevance of existing protected areas off the northeast coast of the Yucatan Peninsula, the Isla Contoy Sea Turtle and the Ria Lagartos sanctuaries. Satellite tracking data from 39 hawksbill (Eretmochelys imbricata), green (Chelonia mydas), and loggerhead turtles were used to show the importance of these protected areas to federal authorities who, as a result, endorsed both sea turtle sanctuaries [48,49] (Figure 1, example 16). In the course of 1 year, there was a shift from a scenario in which the two sea turtle sanctuaries would potentially be abolished, to one in which the tracking data contributed to their maintenance. Likewise, tracking data on withinseason movements by nesting leatherback turtles at Jamursba-Medi, Indonesia, were used to enact legislation to extend protection and include waters adjacent to the nesting beaches [50] (Figure 1, example 17).

Tracking data have also paved the way for new ecosystem-based management approaches, like dynamic ocean management that combines habitat use derived from tracking data with real-time oceanographic data to adaptively protect species (e.g., by reducing bycatch or ship strike risk), while maximizing sustainable use of the ocean [51]. An example of this flexible management is TurtleWatch (https://pifsc.noaa.gov/eod/turtlewatch.php), a tool created in 2008 by NMFS scientists in Hawaii to reduce bycatch of loggerhead turtles in shallow-set longlines [52] (Figure 1, example 18). Fisheries and tag-derived turtle temperature preferences are plotted and disseminated daily to inform fishers where to avoid areas of high bycatch risk. The tool has subsequently been extended to include leatherback turtle movement data and is used regularly by a portion of the fishing community, even though there are no regulatory requirements [53,54]. Similarly, leatherback tracking data are incorporated within the 'EcoCast' model to highlight areas of high bycatch risk relative to target catch in the California drift gillnet fishery for swordfish (Xiphias gladius) [55] (Figure 1, example 19). This model has been shared with both fishers and regional managers and is part of the regulatory process for exempted fishery permit applications that test new gear or methods in the pelagic leatherback turtle conservation area.

In northern Australia, the approval process for oil and gas projects and activities, such as the development of oil and gas extraction and processing facilities, drilling, oil spill preparedness, functioning of the oceans and the services they provide (based on the scientific criteria adopted by the CBD EBSA) to inform marine spatial planning. EBSAs are defined in the $\mathrm{CBD}$ as 'geographically or oceanographically discrete areas that provide important services to one or more species and/or populations of an ecosystem or to the ecosystem as a whole, compared to other surrounding areas or areas of similar ecological characteristics, or otherwise meet the criteria'. Essential Fish Habitat (EFH): defined in the Magnuson-Stevens Fishery Conservation and Management Act as 'those waters and substrate necessary to fish for spawning, breeding, feeding, or growth to maturity'. They represent areas where US fishery management councils need to ensure minimal impacts from fisheries and where actions for conservation are encouraged.

Important Bird and Biodiversity Areas (IBAs): defined by BirdLife International as areas of international significance for birds and other biodiversity, to be identified through robust, standardized criteria, which are amenable to practical conservation actions and can be recognized world-wide as tools to assist conservation. Together these areas are to form an integrated network for conservation.

Important Marine Mammal Areas (IMMAs): an advisory, expert-based, classification of discrete habitats that are important for marine mammal species and that have the potential to be delineated and managed for conservation. IMMAs aim to do for marine mammals and associated biodiversity what IBAs have done for birds over the past few decades.

International Council for

\section{Exploration of the Sea (ICES):} intergovernmental, multidisciplinary science organization with headquarters in Copenhagen, Denmark, focusing on the development of marine research in the North Atlantic (including the adjacent Baltic Sea and North Sea) and on providing scientific advice to member nations.

Marine Protected Areas (MPAs): marine areas where human activities are restricted for biodiversity 


\section{Trends in Ecology \& Evolution}

seismic surveys, and laying of pipelines, often uses sea turtle tracking data to inform the proponent and the regulator of potential risks to turtles (Figure 1, example 20). For example, the ConocoPhillips' Offshore Project Proposal in northern Australia used existing olive ridley turtle tracking data to ensure a gas pipeline did not negatively impact nearby internesting habitat [56]. Clear policy changes are reflected in the Marine Recovery Plan for Marine Turtles in Australia, where tracking studies have helped identify important areas for sea turtles, including internesting buffer distances around rookeries [57].

\section{Pathways to Wider Use of Tracking Data}

From the collective experience portrayed in the examples we included here, it was evident that early engagement between the data collectors and the stakeholders involved in policy development and implementation was often extremely important to help translate tracking data into conservation outcomes. Early engagement can help ensure that tracking programs provide the data and products (maps, analyses, etc.) needed for management rather than simply fulfilling a research agenda $[4,58,59]$. Furthermore, direct communication with managers and policy makers is important because academic publications are often inaccessible to policy makers $[60,61]$. Tracking data alone is insufficient to estimate the threats that species face in different areas, so synergistic use of tracking along with threat and resource maps might help drive the use of tracking data to gain conservation benefits [10]. Our collective case studies illustrate that tracking data can take various pathways into policy and management, and sometimes engagement with stakeholders is not established by the original data collectors (Box 3). In certain cases, progress depended on access to the original tracking data and metadata. In other cases, the accumulated knowledge from many projects (e.g., buffer zones around sea turtle rookeries) was required to shift policy. Data sharing and availability are likely to become increasingly important for fast and successful translation of tracking data into policy. Data sharing is especially important because migratory marine animals often travel vast distances through many geopolitical boundaries, requiring international coordination of conservation efforts to cover their complete distributions $[62,63]$. While the knowledge of species movements increases with the sample size of tracked animals, sometimes relatively small sample sizes (e.g., <10 basking sharks tracked in example 25 in Figure 1), can be sufficient to drive important conservation actions.

In addition to the more direct pathways between tracking data collection and policy change illustrated here, there are many indirect pathways that are difficult to quantify. Tracking data can often make a contribution to decisions via what is termed the 'web of influence' [64]. For example, tracking data can increase public awareness and understanding of animal movements, which in turn can change government actions. Often tracks are displayed on widely viewed websites or through other media, which helps broaden dissemination and impact. Through effective science communication [65], the results of conservation-related tracking studies are being integrated into the consciousness of stakeholders, whose opinions can influence policy $[9,66]$. Tracking data are often a small but integral component of a larger suite of tools that are implemented in policy and management such as MPA design [67]. Tracking data can also provide unexpected information, which is used later to guide management. For example, illegal fishing of sharks within a shark sanctuary was uncovered when satellite tags affixed to sharks transmitting from a boat indicated illegal capture, at-sea transfer, and transport to port [68]. Animal tracking information is also used for a number of purposes not directly linked to conservation, such as observing the physical structure of the world's oceans using sensors incorporated into tags (e.g., [69]). conservation and protection of the marine natural resources. Levels of protection vary and can include reduction or full prohibition of extractive activities (fishing and mining), as in 'marine reserves', or reduction and limitations in development, scientific research, and tourism ('marine parks').

National Marine Fisheries Service (NMFS): federal agency in the USA that manages fisheries sustainability and is responsible for the marine resources in the exclusive economic zone of the USA. NMFS is a division of NOAA, and is also known as NOAA Fisheries.

National Oceanic and Atmospheric Administration (NOAA): scientific agency formed in the 1970s as part of the US Department of Commerce to guide the use and protection of the ocean and coastal resources, monitor the oceanic environment and atmosphere, and do research in the areas of ecosystems, climate, weather and water, and commerce and transportation. 


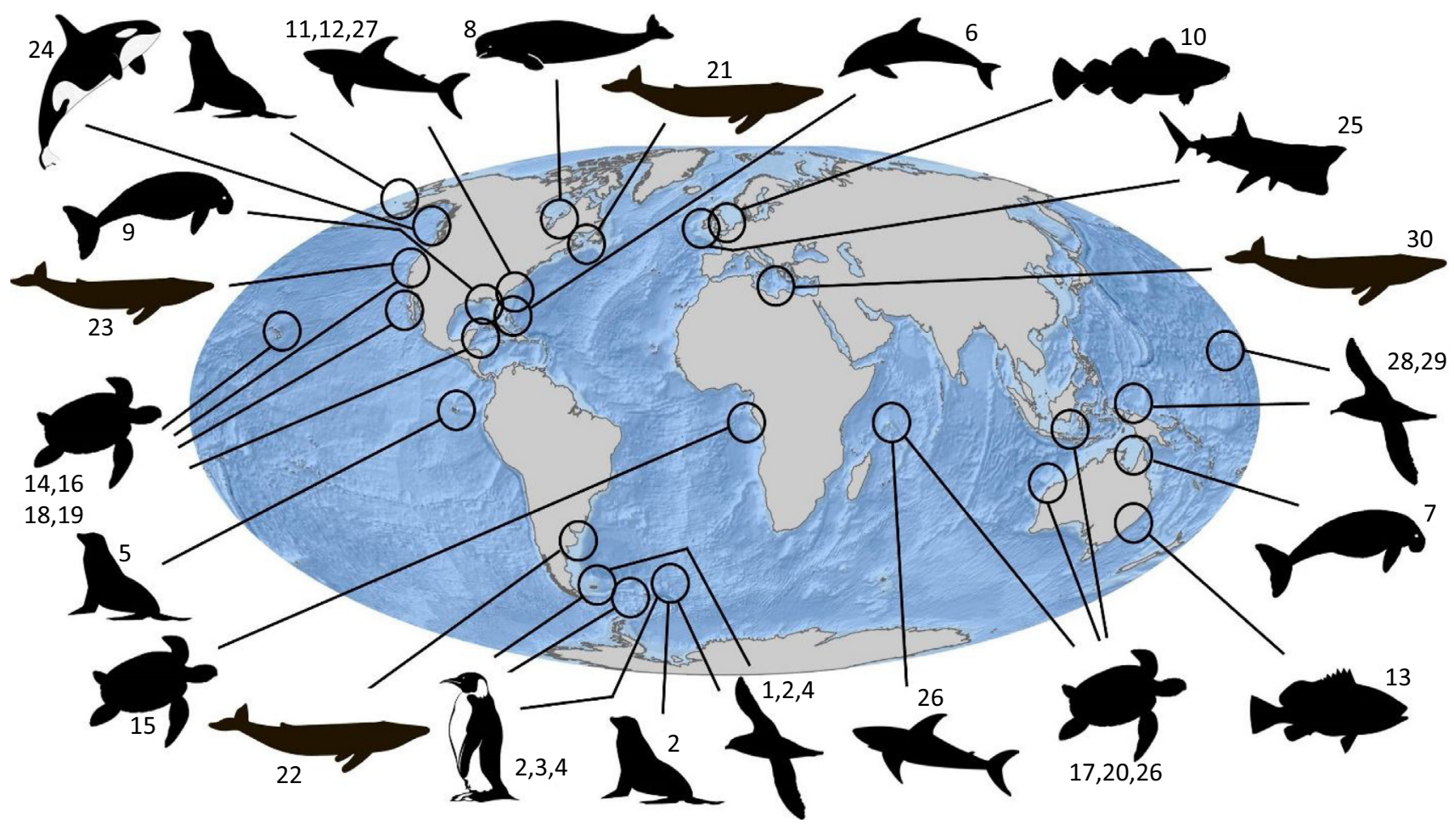

Trends in Ecology \& Evolution

Figure 1. Widespread Use of Marine Animal Tracking Data for Conservation Policy or Management. Tracking data are used in many ways to help species conservation, including being used to help designate protected area boundaries, to reduce bycatch, minimize vessel strikes, assess abundance, and quantify demographic parameters such as mortality rates. Pictured are examples of this breadth of recent research showing the general location of some of our case studies, including data on seabirds (e.g., penguins, albatrosses, and shearwaters), marine mammals (e.g., whales, manatees, dugongs, dolphins, and seals), reptiles (sea turtles), and fish (bony fish and sharks). Examples were selected to illustrate the geographical and taxonomic breadth of where tracking data has driven policy, rather than to objectively identify regional or taxonomic biases where data have been used in this way. Numbers refer to the examples mentioned within each case study in the main text. In some examples several taxa were tracked but only one icon is shown for clarity. 


\section{Trends in Ecology \& Evolution}

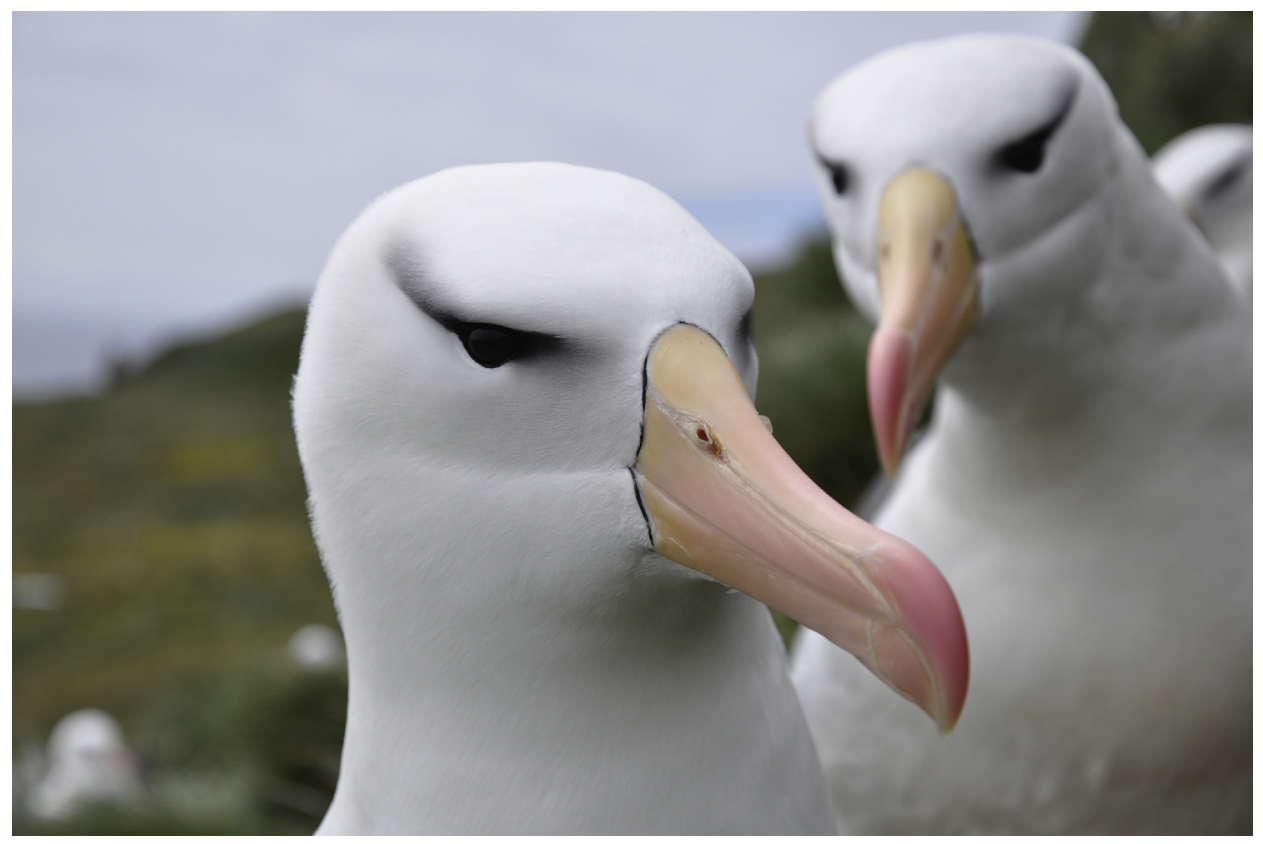

Trends in Ecology \& Evolution

Figure 2. Reducing Bycatch of Seabirds. A black-browed albatross (Thalassarche melanophris). Seabirds are among the most threatened of all birds [70] and, for the medium-sized to large species, a major threat is incidental mortality (bycatch) in commercial fisheries [16,18]. Some of the earliest deployments of satellite transmitters on seabirds were made on wandering albatrosses (Diomedea exulans) in South Georgia [71] and have continued to recent years (Figure 1, example 1). Overlap of bird movements and haul locations of longline vessels targeting Patagonian toothfish (Dissostichus eleginoides) indicated that bycatch risk for wandering albatrosses was greatest during the brood-guard period, leading to a recommendation that fishing should cease from the end of February to mid-May [72]. As a direct consequence, in 1998 the Convention on (or Commission for) the Conservation of Antarctic Marine Living Resources (CCAMLR) implemented a closed fishing season for toothfish, which resulted in a near tenfold reduction in seabird bycatch rates. This fishery remains an exemplar of effective ecosystem-based approach to management [73], with further bycatch mitigation measures being adopted as subsequent tracking results have emerged [16,18]. Photo credit: Richard Phillips.

\begin{abstract}
Box 1. Photo-ID As a Tool to Record Marine Mammal Movements for Conservation Benefit
In some cases the movements and distribution of marine animals are assessed through repeated documentation of scars and natural markings [77], including through photo-ID studies with multiple resightings of individuals used in the same way as tracking data (i.e., visual telemetry; [78]). For example, photo-ID of humpback whales (Megaptera novaeangliae) and North Atlantic right whales (Eubalaena glacialis) revealed they returned each year to the Gulf of Maine, and these data contributed, in 1992, to the declaration of the Stellwagen Bank National Marine Sanctuary in the USA [79]. The value of photo-ID as tracking data to inform management became clear with the growing awareness of the threat of ship strike, which was impacting the endangered North Atlantic right whale as well as humpback and fin whales (Balaenoptera physalus). Working with the International Maritime Organisation, various US government offices, including branches of NOAA and researchers working with the Stellwagen Bank National Marine Sanctuary, largely used whale watching data to determine and mandate the best routing and hull speed for ships to decrease the probability of hitting whales $[80,81]$ (Figure 1, example 21 ).
\end{abstract}

Similar scenarios using photo-ID and sometimes acoustic data to track whales and dolphins have been employed elsewhere around the world. Among those that have led to policy implementation are: (i) southern right whales (Eubalaena australis) off Patagonia, Argentina (Figure 1, example 22), where photo-ID led to management regulations for whale watching and creation of a nursery area off-limits to tourist activities; (ii) gray whales (Eschrichtius robustus) from Mexico to Alaska (Figure 1, example 23), where observer counts tracked the whales and led to expansion of whale watching and initiatives in Mexico and California, in particular to manage whale watching and protect the species; (iii) killer whales (Orcinus orca) in British Columbia and Washington State waters (Figure 1, example 24) where photo-ID and acoustic tracking led to cessation of killer whale captures for aquariums and multiple conservation initiatives from US and Canadian governments to address the declining numbers (e.g., critical habitat identification by the Canadian Department of Fisheries and Oceans and NOAA, and the Vancouver Harbor Low Noise Directive to reduce noise pollution impacts). 


\section{Trends in Ecology \& Evolution}

\section{CellPress \\ REVIEWS}

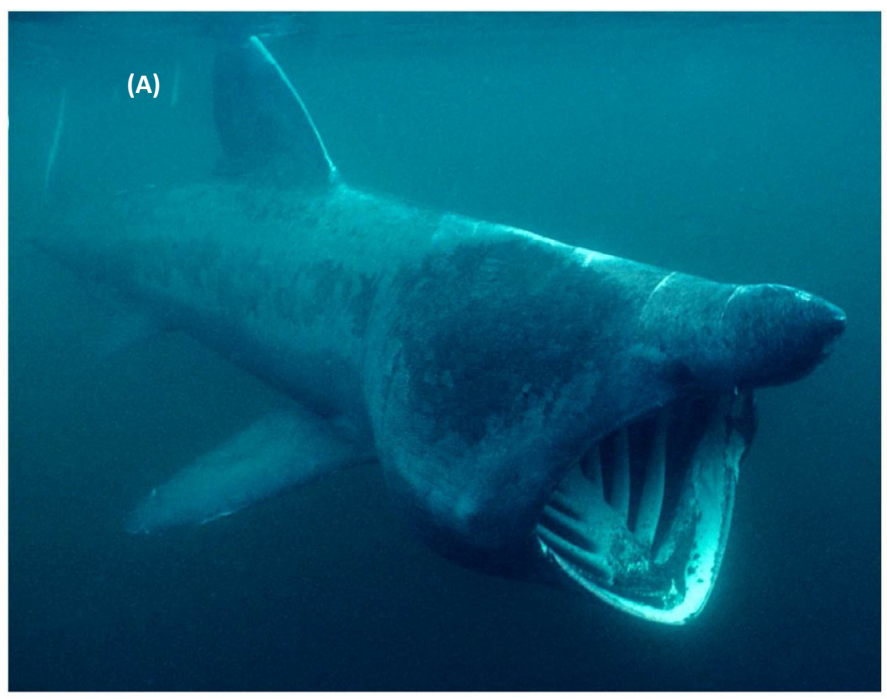

(B)

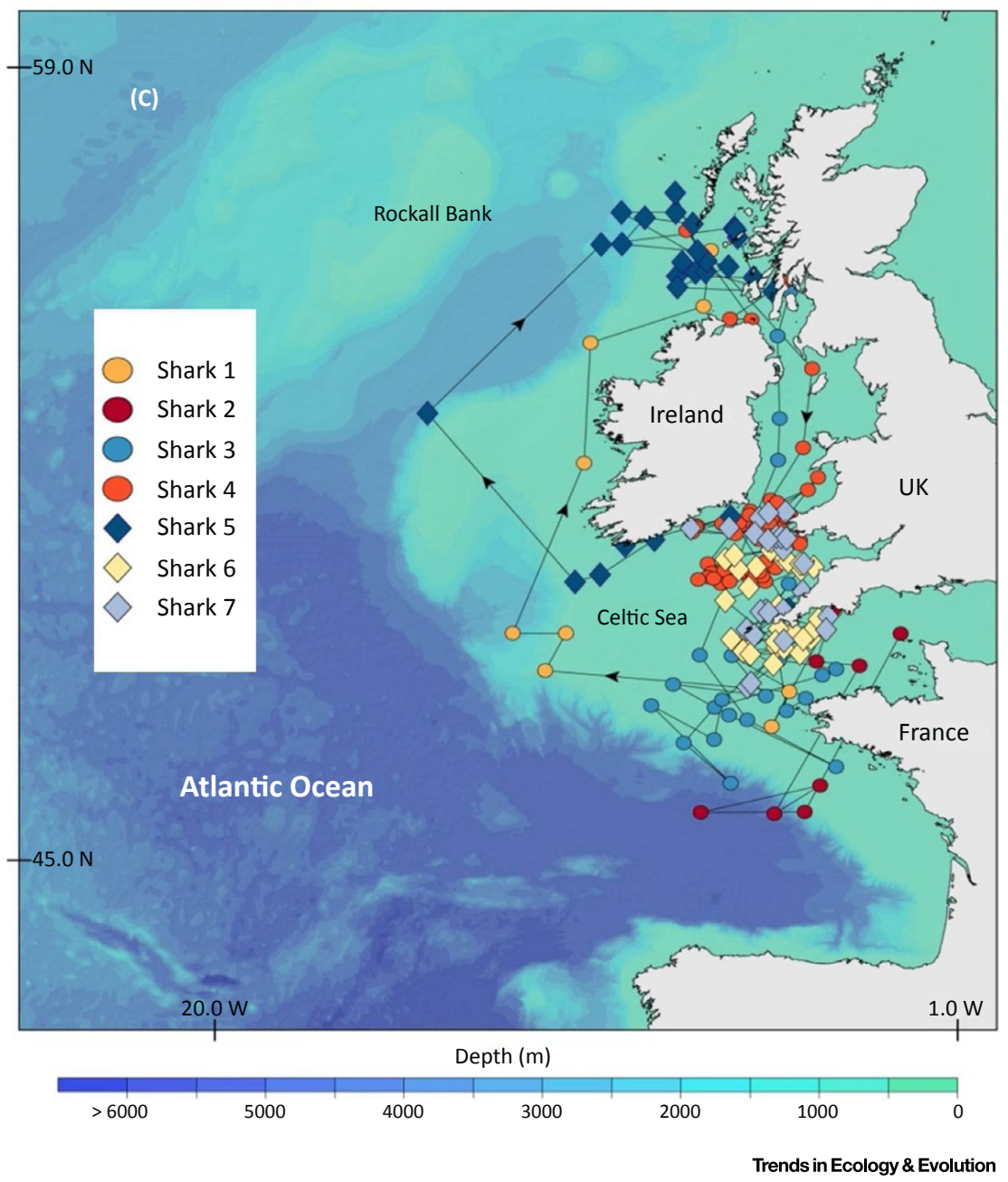




\section{Trends in Ecology \& Evolution}

Box 2. Using Tracking Data to Inform Conservation at Different Spatial Scales

Tracking data have been used to effect policy change over scales of a few kilometers up to massive ocean areas. For example, around the Seychelles island of D'Arros and atoll of St Joseph, a detailed understanding of shark and turtle spatial ecology is being used to greatly extend the boundary of a no-take MPA [82] (Figure 1, example 26). Using acoustic tags relaying data to an array of passive acoustic receivers, 116 sharks of five different species and 25 hawksbill turtles were tracked during 2012-2015. Based on these movement data, increasing the size of the MPA from $42.3 \mathrm{~km}^{2}$ to $64.9 \mathrm{~km}^{2}$ was justified. Initial results were shared in meetings with the Ministry of Environment, Energy, and Climate Change, which contributed to the government of Seychelles adopting the larger MPA and continuing to use the acoustic tracking data in ongoing MPA refinements. Similarly, acoustic tracking of juvenile bull sharks (Carcharhinus leucas) and smalltooth sawfish (Pristis pectinata) in the Caloosahatchee River, Florida, revealed direct responses of individuals to changes in river flow rates, which were altered through the opening and closing of a lock on the river [83,84] (Figure 1, example 27). The observed redistribution of fish based on the water flow regime resulted in the Southwest Florida Water Management District changing their practices to release water from the lake more slowly rather than large pulse events, reducing physiological stress in bull sharks and sawfish. At a much larger scale, tracking data for several seabird species, along with sea turtles, sharks, and marine mammals, showed that the original boundaries of two large-scale MPAs, Papahānaumokuākea and the Pacific Remote Islands Marine National Monuments, were not capturing the entire habitat of these species and were key components of the scientific justification for the expansion of these MPAs [85-87]. In 2016, Papahānaumokuākea was extended to 1.5 million $\mathrm{km}^{2}$, which is three times its original size, and the Pacific Remote Islands increased to 1.27 million $\mathrm{km}^{2}$, six times its original size (Figure 1, example 28).

Figure 3. Tracking Data Driving the International Conservation Status of Marine Animals. In 2001, basking shark (Cetorhinus maximus) (A) migration was studied for the first time using pop-off satellite-linked archival transmitters (PSAT tags; B) (Figure 1, example 25). Sharks were shown to be highly migratory, travelling thousands of kilometers in a few weeks, but at the same time remaining faithful to rich feeding areas on the continental shelf and shelf edges (C; redrawn from [74]). Circular markers on tracks denote sharks tagged in 2001; diamonds, 2002. This research informed a key re-interpretation of the basking shark catch declines seen worldwide during the 20th century by revealing that area-focused fisheries could potentially overexploit a population. The UK Government, through their Department for Environment, Food, and Rural Affairs Global Wildlife Division, incorporated the new results and interpretations into its 2002 proposal to attain listing of basking sharks on Appendix II of the Convention on International Trade in Endangered Species of Fauna and Flora (CITES). Appendix II requires that international trade of these species is monitored through a licensing system to ensure that trade can be sustained without detriment to wild populations. Previous attempts to list the basking shark on CITES had failed, including in the year 2000, prior to the tracking research being undertaken. However, in November 2002 at the CITES Conference of Parties meeting in Santiago, Chile, the UK Government-led proposal for basking shark Appendix II listing was passed, effective from February 2003. This was a landmark for CITES in that it addressed commercially exploited marine fish for the first time. Further tracking data showed that basking sharks moved regularly across many national boundaries before coming back to 'home' areas [75]. This research underpinned the successful UK-led proposal in November 2005 to list basking sharks on Appendix II of the Convention for the Conservation of Migratory Species of Wild Animals (CMS) (the Bonn Convention). Listing under the convention means that nation states with basking shark populations must work with adjacent member states to introduce strict legislation to prevent capture and landing of the shark. The listing of basking shark on CITES and CMS also played a key role in putting in place an outright ban on EU vessels catching, keeping on board, or landing basking sharks inside and outside European waters from 2007 (Article 5.6, European Commission Regulation No. 41/2007) [76]. The research has contributed to the basking shark becoming one of the most protected species of shark. Photo credits: Jeremy Stafford-Deitsch (A), David Sims (B), Nuno Queiroz (C). 


\section{Trends in Ecology \& Evolution}

\section{CellPress \\ REVIEWS}

Box 3. Pathways for Uptake of Tracking Data into Policy and Management are Varied and Often Follow Efforts to Identify 'Important Areas' Often a key step in the implementation of conservation policy from tracking data has been the objective identification of key areas (e.g., high use by animals or where threats are high) by international conservation bodies. For example, the BirdLife International database (http://seabirdtracking.org) has been used to identify marine Important Bird and Biodiversity Areas (IBAs) worldwide [88,89]. These areas have been used to inform marine policy processes at national, regional, and global scales [89]. In Europe, many IBAs are now part of the network of sites designated as special protection areas under the Birds Directive [90]. Since 2012, BirdLife International has also been working in collaboration with the Convention on Biological Diversity (CBD) in the process of describing ecologically or biologically significant areas (EBSAs) globally. To date, more than 600 marine IBAs, mostly identified using tracking data, are included in EBSAs. While the description of EBSAs by the CBD is a technical exercise that has no direct management implications, the information generated during the EBSA process has been conveyed to the Parties (i.e., countries), the United Nations, and to regional and sectoral organizations with management competency in areas beyond national jurisdiction [91]. This can lead to uptake of that information and the development of conservation management measures, such as MPAs and marine spatial planning. For example, tracking the year-round movements of streaked shearwaters (Calonectris leucomelas) breeding in Japan using leg-mounted geolocators [92] identified a key wintering area to the north of northern New Guinea, which was approved as an EBSA in 2011 (cbdint/doc/meetings/mar/rwebsa-wspac-01/official/ rwebsa-wspac-01-sbstta-16-inf-06-en.pdf) and has now been selected as a priority area of conservation interest by the government of Papua New Guinea [93] (Figure 1, example 29). Likewise in 2016, a new tool for the spatial conservation of marine mammals was launched by the International Union for Conservation of Nature: Important Marine Mammal Areas (IMMAs). For example, presence of fin whale feeding habitat has been identified as the 'North West Mediterranean Sea, Slope, and Canyon System' IMMA (Figure 1, example 30). A recent resolution (Resolution 12.13 adopted in October 2017 by the 12 th Conference of Parties to the CMS [94]), made IMMAs a formal part of the CMS agreement mandate, asking countries to help with the identification and implementation of IMMAs and are depicted in Figure I (refer to Glossary and main text for definitions).

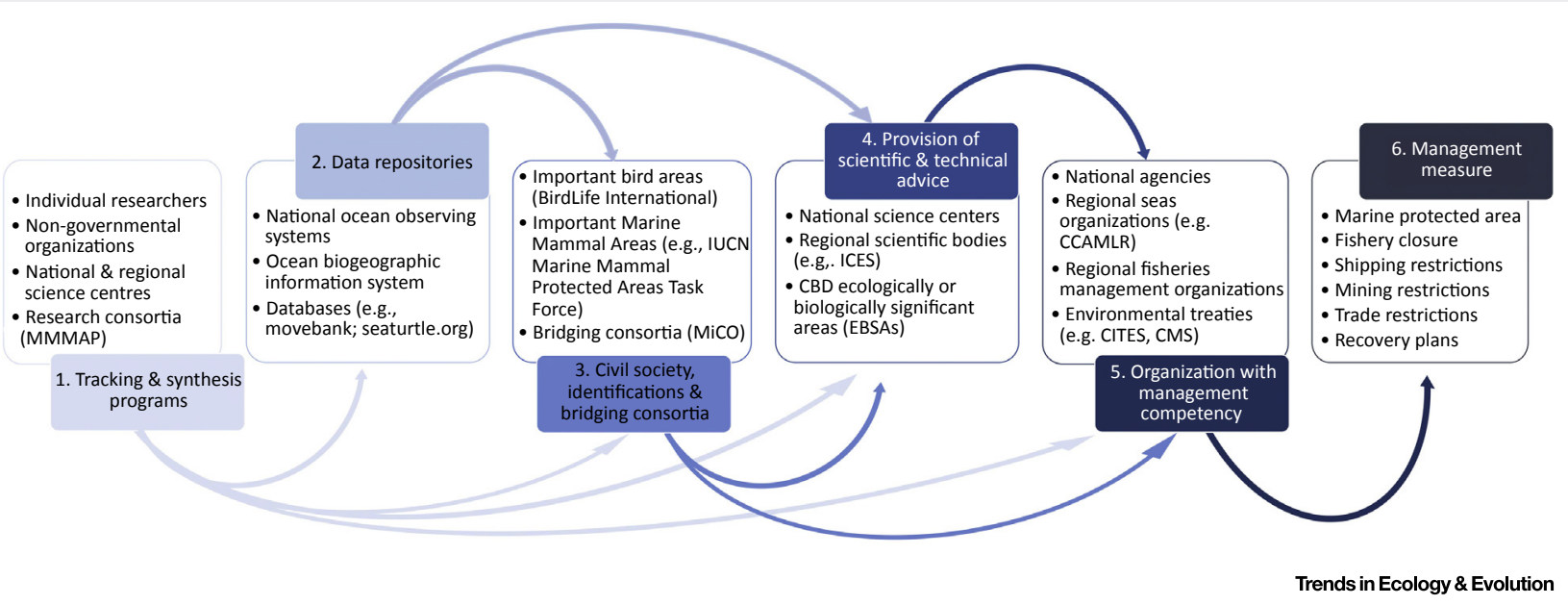

Figure I. The Various Steps Tracking Data Might Pass through Before Uptake into Management Measures. CCAMLR, Convention on (or Commission for) the Conservation of Antarctic Marine Living Resources; CBD, Convention on Biological Diversity; CITES, Convention on International Trade in Endangered Species of Fauna and Flora; CMS, Convention on Migratory Species of Wild Animals; EBSA, ecologically or biologically significant area; ICES, International Council for Exploration of the Sea; IUCN, International Union for Conservation of Nature; MiCO, Migratory Connectivity in the Oceans; MMMAP, Marine Megafauna Movement Analytical Program. 


\section{Trends in Ecology \& Evolution}

CellPress REVIEWS

\section{Concluding Remarks}

While our compilation of case studies is far from exhaustive, it is heartening to find documentable global examples among diverse marine taxa where tracking data influenced conservation policy and management. The clear message that emerges from this compilation is that regardless of taxa or geographic areas, there are many precedents providing guidance on the means of applying tracking data to better safeguard marine taxa at local to regional scales. We suspect that a large number of existing datasets, published and unpublished, could better contribute to conservation (see Outstanding Questions). Tracking data can provide a conservation legacy long after the original study has finished, with conservation benefits sometimes emerging years later, highlighting the value of tracking data being available in perpetuity. We hope that these success stories will encourage wider data sharing and collaboration among researchers and policy makers for the conservation benefit of the species they study.

\section{Author Contributions}

G.C.H., C.Y.K., D.C.D., A.M.M.S., D.P.C., and P.N.H. conceived the paper; G.C.H. led the writing with help from A.M.M.S All authors contributed text for case studies or intellectual input on the content and helped edit drafts.

\section{Acknowledgments}

G.C.H. and N.E. were supported by the Bertarelli Foundation as part of the Bertarelli Programme in Marine Science. A.M. M.S. was supported by an ARC Grant DE170100841 and by AIMS. R.H.C. thanks Elizabeth Hieb and Kayla DaCosta for assistance with compilation of tag data and applications.

\section{References}

1. Hussey, N.E. et al. (2015) Aquatic animal telemetry: a panoramic window into the underwater world. Science 348, 1255642

2. Kays, R. et al. (2015) Terrestrial animal tracking as an eye on life and planet. Science 348, aaa2478

3. Fraser, K.C. et al. (2018) Tracking the conservation promise of movement ecology. Front. Ecol. Evol. 6, 150

4. McGowan, J. et al. (2017) Integrating research using animalborne telemetry with the needs of conservation management. J. Appl. Ecol. 54, 423-429

5. Jeffers, V.F. and Godley, B.J. (2016) Satellite tracking in sea turtles: how do we find our way to the conservation dividends? Biol. Conserv. 199, 172-184

6. Hays, G.C. et al. (2016) Key questions in marine megafauna movement ecology. Trends Ecol. Evol. 6, 463-475

7. Ogburn, M.B. et al. (2017) Addressing challenges in the application of animal movement ecology to aquatic conservation and management. Front. Mar. Sci. 4, 70

8. Lascelles, B.G. et al. (2016) Applying global criteria to tracking data to define important areas for marine conservation. Divers. Distrib. 22, 422-431

9. Nguyen, V.M. et al. (2017) To share or not to share in the emerging era of big data: perspectives from fish telemetry researchers on data sharing. Can. J. Fish. Aquat. Sci. 74, 1260-1274

10. Maxwell, S.M. et al. (2013) Cumulative human impacts on marine predators. Nat. Commun. 4, 2688

11. Queiroz, N. et al. (2016) Ocean-wide tracking of pelagic sharks reveals extent of overlap with longline fishing hotspots. Proc. Natl. Acad. Sci. U. S. A. 113, 1582-1587

12. Sequeira, A.M.M. et al. (2018) Convergence of marine megafauna movement patterns in coastal and open oceans. Proc. Natl. Acad. Sci. U. S. A. 15, 3072-3077

13. Trathan, P.N. et al. (2014) The South Georgia and the South Sandwich Islands MPA: protecting a biodiverse oceanic island chain situated in the flow of the Antarctic Circumpolar Current. Adv. Mar. Biol. 69, 15-78

14. Warwick-Evans, V. et al. (2018) Using habitat models for chinstrap penguins Pygoscelis antarctica to advise krill fisheries management during the penguin breeding season. Divers. Dis-

15. Trathan, P.N. et al. (2018) Managing fishery development in sensitive ecosystems: identifying penguin habitat use to direct management in Antarctica. Ecosphere 9, e02392

16. Augé, A.A. et al. (2018) Framework for mapping key areas for marine megafauna to inform marine spatial planning: the Falkland Islands case study. Mar. Policy 92, 61-72 Sites for Wider Marine Management in the Falkland Islands AFCAS. Post-Consultation Stakeholder Workshop, SAERI

18. Phillips, R.A. et al. (2016) The conservation status and priorities

19. Villegas-Amtmann, S. et al. (2013) Individual foraging strategies reveal niche overlap between endangered Galapagos pinnipeds. PLoS One 8, e70748

20. Scott, G.P. (1990) Management-oriented research on bottlenose dolphins by the Southeast Fisheries Center. In The Bottlenose Dolphin (Leatherwood, S. and Reeves, R.R., eds), pp. 623-639, Academic Press

21. Irvine, A.B. et al. (1981) Movements and activities of the Atlantic bottlenose dolphin Tursiops truncatus, near Sarasota, Florida. Fish. Bull. 79, 671-688

22. Blaylock, R.A. et al. (1995) U.S. Atlantic and Gulf of Mexico Marine Mammal Stock Assessments, NOAA Tech. Mem. NMFS-SEFSC363, pp. 1-211.

23. Hagihara, R. et al. (2016) Improving the Estimates of Abundance of Dugongs and Large Immature and Adult-Sized Green Turtles in Western and Central Torres Strait. Report to the National Environmental Science Programme, Reef and Rainforest Research Centre Limited, (Cairns)

24. Sheppard, J. et al. (2006) Movement heterogeneity of dugongs, Dugong dugon Müller over large spatial scales. J. Exp. Mar. Biol. Ecol. 334, 64-83

25. Marsh, H. (2000) Evaluating management initiatives aimed at reducing the mortality of dugongs in gill and mesh nets in the Great Barrier Reef World Heritage Area. Mar. Mamm. Sci. 16 684-694 trib. 24, 1756-1771

17. Golding, N. (2017) The Assessment of Fishing Closure Areas as for albatrosses and large petrels. Biol. Conserv. 201, 169-183

\section{Outstanding Questions}

What is the best way to ensure tracking data uptake for conservation and management? While the benefits of tracking data to conservation and management are clear after this compilation of examples, defining the best way to ensure uptake is still unclear. Greater dialogue between policy makers (including key politicians and their staff), management organizations, and research institutions, particularly during the early stages of research planning, should assist defining clearer pathways for uptake of research results based on tracking data for management measures. At the same time, novel data showing the importance of specific areas can highlight the lack of adequate legal instruments to efficiently manage those areas (e.g., in international waters) and hence can be used to promote the development of such instruments in the first place.

How can the 'lessons learned' in one scenario be best transferred to other cases? Our compilation highlights examples of how tracking data for various taxa or geographic areas have led to policy changes; however, how these precedents might be better used to inform and drive policy elsewhere has not been fully explored, and is partly due to insufficient communication among specialists on different taxa.

How can the use of tracking data be quantified when uptake occurs indirectly? The influence of tracking results on the general public through science communication can lead to government actions. As we move forward, it will be important to ensure that the original data and efforts leading to management actions are acknowledged. 


\section{Trends in Ecology \& Evolution}

26. Dobbs, K. et al. (2008) Incorporating dugong habitats into the marine protected area design for the Great Barrier Reef Marine Park, Queensland, Australia. Ocean Coast. Manag. 51, 368-375

27. Lewis, A.E. et al. (2009) Movement and aggregation of eastern Hudson Bay beluga whales (Delphinapterus leucas): a comparison of patterns found through satellite telemetry and Nunavik traditional ecological knowledge. Arctic 62, 13-24

28. Bailleul, F. et al. (2012) Migration phenology of beluga whales in a changing Arctic. Clim. Res. 53, 169-178

29. DFO (2018) Harvest Advice for Eastern and Western Hudson Bay Beluga (Delphinapterus leucas). DFO Can. Sci. Advis. Sec. Sci. Advis. Rep. 2018/008

30. Aven, A. et al. (2016) West Indian manatee movements reveal novel occupancy and distribution patterns in the northern Gulf of Mexico. PeerJ 4, e2072v1

31. Adimey, N.M. et al. (2016) Twenty-six years of post-release monitoring of Florida manatees (Trichechus manatus latirostris): evaluation of a cooperative rehabilitation program. Aquat. Mamm. 42, 376-391

32. Righton, D. et al. (2007) Movements and distribution of cod (Gadus morhua) in the southern North Sea and English Channel: results from conventional and electronic tagging experiments. J. Mar. Biol. Assoc. U. K. 87, 599-613

33. Marshall, H. et al. (2015) At-vessel and post-release mortality of the dusky (Carcharhinus obscurus) and sandbar (C. plumbeus) sharks after longline capture. Fish. Res. 172, 373-384

34. Sulikowski, J.A. et al. (2018) Evaluating the condition and discard mortality of winter skate, Leucoraja ocellata, following capture and handling in the Atlantic monkfish (Lophius americanus) sink gillnet fishery. Fish. Res. 198, 159-164

35. National Oceanic and Atmospheric Administration (2015) Final Essential Fish Habitat 5-Year Review for Atlantic Highly Migratory Species, NOAA

36. Heupel, M.R. and Simpfendorfer, C.A. (2002) Estimation of mortality of juvenile blacktip sharks, Carcharhinus limbatus, within a nursery area based on telemetry data. Can. J. Fish. Aquat. Sci. 59, 624-632

37. SEDAR (2006) SEDAR 11 Stock Assessment Report Large Coastal Shark Complex, Blacktip and Sandbar Shark. Southeast Data, Assessment, and Review Final Report, NOAA Fisheries

38. Lee, K. et al. (2015) Size isn't everything: movements, home range, and habitat preferences of eastern blue gropers (Achoerodus viridis) demonstrate the efficacy of a small marine reserve. Aquat. Conserv. 25, 174-186

39. Wingfield, D.K. et al. (2011) The making of a productivity hotspot in the coastal ocean. PLoS One 6, e27874

40. Senko, J. et al. (2017) At loggerheads over international bycatch: initial effects of a unilaterally imposed bycatch reduction policy. Mar. Policy 76, 200-209

41. DOF [Diario Oficial de la Federación] (2016) Acuerdo por el que Establece la Zona de Refugio Pesquero y Nuevas Medidas para Reducir la Posible Interacción de la Pesca con Tortugas Marinas en la Costa Occidental de Baja California Sur. Secretaria de la Gobernación

42. Peckham, S.H. et al. (2007) Small-scale fisheries bycatch jeopardizes endangered Pacific loggerhead turtles. PLoS One 2, e1041

43. Seminoff, J.A. et al. (2014) Loggerhead sea turtle abundance at an offshore foraging hotspot in the eastern Pacific Ocean: implications for at-sea conservation. Endanger. Species Res. 24, $207-$ 220

44. Maxwell, S.M. et al. (2011) Using satellite tracking to optimize protection of long-lived marine species: olive ridley sea turtle conservation in Central Africa. PLoS One 6, e19905

45. Casale, P. et al. (2017) A first estimate of sea turtle bycatch in the industrial trawling fishery of Gabon. Biodivers. Conserv. 26, 2421-2433

46. Dawson, T.M. et al. (2017) Informing marine protected area designation and management for nesting olive ridley sea turtles using satellite tracking. Front. Mar. Sci. 4, 312
47. Pikesley, S.J. et al. (2018) A novel approach to estimate the distribution, density and at-sea risks of a centrally-placed mobile marine vertebrate. Biol. Conserv. 221, 246-256

48. Cuevas, E. et al. (2010) Post-nesting migratory movements of hawksbill turtles (Eretmochelys imbricata) around the Yucatan Peninsula, Mexico. Endanger. Species Res. 10, 123-133

49. Méndez, D. et al. (2013) Rastreo satelital de tortugas blanca hembra Chelonia mydas, y evaluación de sus ámbitos hogareños en la costa norte de la península de Yucatán, México. Rev. Biol. Mar. Oceanogr. 3, 497-509

50. Hitipeuw, C. et al. (2007) Population status and inter-nesting movement of leatherback turtles, Dermochelys coriacea, nesting on the northwest coast of Papua, Indonesia. Chelonian Conserv. Biol. 6, 28-36

51. Maxwell, S.M. et al. (2015) Dynamic ocean management: defining and conceptualizing real-time management of the ocean. Mar. Policy 58, 42-50

52. Howell, E.A. et al. (2008) TurtleWatch: a tool to aid in the bycatch reduction of loggerhead turtles Caretta caretta in the Hawailbased pelagic longline fishery. Endanger. Species Res. 5, 267278

53. Howell, E.A. et al. (2015) Enhancing the TurtleWatch product for leatherback sea turtles, a dynamic habitat model for ecosystembased management. Fish. Oceanogr. 24, 57-68

54. Lewison, R. et al. (2015) Dynamic ocean management: identifying the critical ingredients of dynamic approaches to ocean resource management. Bioscience 65, 486-498

55. Hazen, E.L. et al. (2018) A dynamic ocean management tool to reduce bycatch and support sustainable fisheries. Sci. Adv. 4 eaar3001

56. ConocoPhillips Australia (2018) Barossa Area Development: Offshore Project Proposal, ConocoPhillips

57. Department of Environment and Energy (2017) Recovery Plan for Marine Turtles in Australia, Commonwealth of Australia

58. Bailey, H. et al. (2018) Lessons learned from WhaleWatch, a tool using satellite data to provide near-real-time predictions of whale occurrence. In Satellite Remote Sensing for Conservation Action: Case Studies of Implementation (Buchanan, G.M. and Leidner, A K., eds), pp. 229-273, Cambridge University Press

59. Brooks, J.L. et al. (2018) Biotelemetry informing management: case studies exploring successful integration of biotelemetry data into fisheries and habitat management. Can. J. Fish. Aquat. Sci. Published online August 16, 2018. http://dx.doi.org/10.1139/ cifas-2017-0530

60. Pietri, D.M. et al. (2013) Practical recommendations to help students bridge the research-implementation gap and promote conservation. Conserv. Biol. 27, 958-967

61. Sunderland, T. et al. (2009) Bridging the gap: how can information access and exchange between conservation biologists and field practitioners be improved for better conservation outcomes? Biotropica 41, 549-554

62. Harrison, A.-L. et al. (2018) The political biogeography of migra tory marine predators. Nat. Ecol. Evol. 2, 1571-1578

63. Fossette, S. et al. (2014) Pan-Atlantic analysis of the overlap of a highly migratory species, the leatherback turtle, with pelagic longline fisheries. Proc. R. Soc. B 281, 20133065

64. British Academy (2016) Lord Stern's Review of the Research Excellence Framework: A Response from the British Academy, British Academy, (London)

65. Cooke, S.J. et al. (2017) Considerations for effective science communication. FACETS 2, 233-248

66. Campbell, H.A. et al. (2015) Finding our way: on the sharing and reuse of animal telemetry data in Australasia. Sci. Total Environ. $534,79-84$

67. Lombard, A.T. et al. (2007) Conserving pattern and process in the Southern Ocean: designing a marine protected area for the Prince Edward Islands. Antarct. Sci. 19, 39-54

68. Bradley, D. et al. (2018) Leveraging satellite technology to create true shark sanctuaries. Conserv. Lett. e12610 


\section{Trends in Ecology \& Evolution}

69. Pauthenet, E. et al. (2018) Seasonal meandering of the Polar Front upstream of the Kerguelen Plateau. Geophys. Res. Lett. 45, 9774-9781

70. Croxall, J.P. et al. (2012) Seabird conservation status, threats and priority actions: a global assessment. Bird Conserv. Int. 22, 1-34

71. Prince, P.A. et al. (1992) Satellite tracking of wandering albatrosses (Diomedea exulans) in the South Atlantic. Antarct. Sci. 4, 31-36

72. Croxall, J. and Prince, P. (1996) Potential interactions between wandering albatrosses and longline fisheries for Patagonian toothfish at South Georgia. CCAMLR Sci. 3, 101-110

73. Croxall, J.P. and Nicol, S. (2004) Management of Southern Ocean fisheries: global forces and future sustainability. Antarct. Sci. 16, 569-584

74. Sims, D.W. et al. (2003) Seasonal movements and behaviour of basking sharks from archival tagging: no evidence of winter hibernation. Mar. Ecol. Prog. Ser. 248, 187-196

75. Southall, E.J. et al. (2006) Seasonal space-use estimates of basking sharks in relation to protection and political-economic zones in the North-east Atlantic. Biol. Conserv. 132, 33-39

76. Sims, D.W. (2008) Sieving a living: a review of the biology, ecology and conservation status of the plankton-feeding basking shark Cetorhinus maximus. Adv. Mar. Biol. 54, 171-220

77. Wells, R.S. et al. (2018) Identification methods. In Encyclopedia of Marine Mammals (3rd edn) (Würsig, B., ed.), pp. 503-509, Academic Press/Elsevier

78. Priede, I.G. (1992) Wildlife telemetry: an introduction. In Wildlife Telemetry (Priede, I.G. and Swift, S.M., eds), pp. 3-25, Ellis Horwood

79. Hoyt, E. (2011) Marine Protected Areas for Whales, Dolphins and Porpoises: A World Handbook for Cetacean Habitat Conservation and Planning, Earthscan/Routledge and Taylor \& Francis

80. International Whaling Commission (2014) Report of the Joint IWC-SPAW Workshop to Address Collisions between Marine Mammals and Ships with a Focus on the Wider Caribbean, IWC/65/CCRep01

81. Wiley, D.N. et al. (2011) Modeling speed restrictions to mitigate lethal collisions between ships and whales in the Stellwagen Bank National Marine Sanctuary, USA. Biol. Conserv. 144, 2377-2381

82. Lea, J.S.E. et al. (2016) Acoustic telemetry and network analysis reveal the space use of multiple reef predators and enhance marine protected area design. Proc. R. Soc. B 283 , 20160717

83. Heupel, M.R. and Simpfendorfer, C.A. (2008) Movement and distribution of young bull sharks Carcharhinus leucas in a variable estuarine environment. Aquat. Biol. 1, 277-289

84. Simpfendorfer, C.A. et al. (2011) Environmental influences on the spatial ecology of juvenile smalltooth sawfish (Pristis pectinata): results from acoustic monitoring. PLoS One 6, e16918

85. Maxwell, S.M. and Morgan, L.E. (2013) Facilitated foraging of seabirds on pelagic fishes: implications for management of pelagic marine protected areas. Mar. Ecol. Prog. Ser. 481 289-303

86. Young, H.S. et al. (2015) Pelagic marine protected areas provide effective habitat protection for multiple seabird species. Biol. Conserv. 181, 226-235

87. Kerr, J. et al. (2016) Pu'uhonua a Place of Sanctuary: The Cultural and Biological Significance of the Proposed Expansion for the Papahānaumokuākea Marine National Monument, Expand Papahānaumokuākea

88. Dias, M.P. et al. (2017) Using globally threatened pelagic birds to identify priority sites for marine conservation in the South Atlantic Ocean. Biol. Conserv. 211, 76-84

89. Lascelles, B.G. et al. (2012) From hotspots to site protection: identifying marine protected areas for seabirds around the globe. Biol. Conserv. 156, 5-14

90. Ramirez, I. et al. (2017) How well is the EU protecting its seabirds? Progress in implementing the Birds Directive at sea. Mar. Policy 81, 179-184

91. Dunn, D.C. et al. (2014) The Convention on Biological Diversity's Ecologically or Biologically Significant Areas: origins, development, and current status. Mar. Policy 49, 137-145

92. Yamamoto, T. et al. (2010) At-sea distribution and behaviour of streaked shearwaters (Calonectris leucomelas) during the nonbreeding period. Auk 127, 871-881

93. Government of Papua New Guinea (2015) National Marine Conservation Assessment for Papua New Guinea, Conservation and Protection Authority

94. Convention on Migratory Species (2017) Important Marine Mammal Areas (IMMAs). Resolution 12.13 Adopted by the Conference of the Parties at its 12th Meeting (Manila, October 2017), CMS 